UDC 624.155

DOI: $10.32326 / 1814-9146-2019-81-2-233-239$

\title{
A MODEL OF PILE DRIVING BY MULTIPLE IMPACTS OF FALLING HAMMER
}

\author{
Dubinsky A.V.
}

\author{
Ben-Gurion University of the Negev, Beer-Sheva, Israel \\ dubin@bgu.ac.il
}

Received by the Editor 2019/06/07

Calculations related to pile driving play an important role in construction. Therefore, corresponding processes are controlled by regulatory documents, including the necessary formulas, which are accompanied by numerous tables and graphs, allowing the use of techniques in specific conditions of construction. The basis of such applied methods are the results of research in mechanics; the results of such studies are widely presented in the literature. This article is made within the framework of such studies.

The article presents an approximate approach based on the evaluation of the real values of the parameters that determine the process of driving the pile. The proposed approach allowed to obtain an approximate formula to calculate the motion of the pile in soil by successive blows of the hammer falling freely. The following ways to analyze and improve models within this approach are outlined: (1) analysis of the accuracy of the proposed model by its presentation with the results of experiments and calculations using other models as well as with recommendations of normative instruments; (2) generalization of the model for the case when the mechanical properties of the soil vary depending on the depth of immersion into the soil.

Keywords: ground, pile, penetration, hammer, driving, modeling, calculation.

\section{Introduction}

Calculations related to pile driving play an important role in construction. Therefore, corresponding processes are controlled by regulatory documents, including the necessary formulas, which are accompanied by numerous tables and graphs $[1,2]$, allowing the use of techniques in specific conditions of construction. The basis of such applied methods are the results of research in mechanics; the results of such studies are widely presented in the literature (for instance, [3-13]). This article is made within the framework of such studies.

\section{Formulation of the problem and mathematical model}

Consider a pile with a square cross section and pyramidal shape of the nose driving into soil by falling hammer (Fig. 1). When the nose is submerged in the ground to a depth of $h$ and the hammer falls on the head of the pile from a height $H$ the energy conservation 
equation can be written as follows:

$$
M g H=M g\left[L-h^{(i)}+e\right]+0.5 M V^{(i) 2},
$$

where $M$ is mass of hammer, $H$ is height of center of mass of hammer at beginning of fall, $g$ is acceleration of gravity, $L$ is pile length including nose, $h^{(i)}$ is distance from nose of pile to surface of soil prior to its movement after $i^{\text {th }}$ impact, $e$ is half the height of hammer, $V^{(i)}$ is speed of hammer before $i^{\text {th }}$ blow on pile.

Assuming that after the inelastic impact hammer and the pile continue to move as a single unit one can write:

$$
M V^{(i)}=(M+m) v^{(i)},
$$

where $m$ is mass of pile, $v^{(i)}$ is initial speed of hammer-pile construction after $i^{\text {th }}$ impact on pile.

Eliminating $V^{(i)}$ from Eqs. (1) and (2), we obtain:

$$
w^{(i)}=\gamma_{1} h^{(i)}+\gamma_{0},
$$

where $w^{(i)}=v^{(i) 2}$ and

$$
\gamma_{1}=2 g\left(\frac{M}{M+m}\right)^{2}, \quad \gamma_{0}=2 g\left(\frac{M}{M+m}\right)^{2}[H-L-e] .
$$

Similar to [10], we use the local interaction model [14] in the version of Vitman and Stepanov [15] to calculate the resistance of the nose of the pile:

$$
p=Y_{\text {soil }}+\rho_{\text {soil }} v_{n}^{2},
$$

where $p$ is pressure on nose surface of pile, $Y_{\text {soil }}$ is dynamic hardness of soil, $\rho_{\text {soil }}$ is density of soil, $v_{n}$ is normal component of speed on nose of pile.

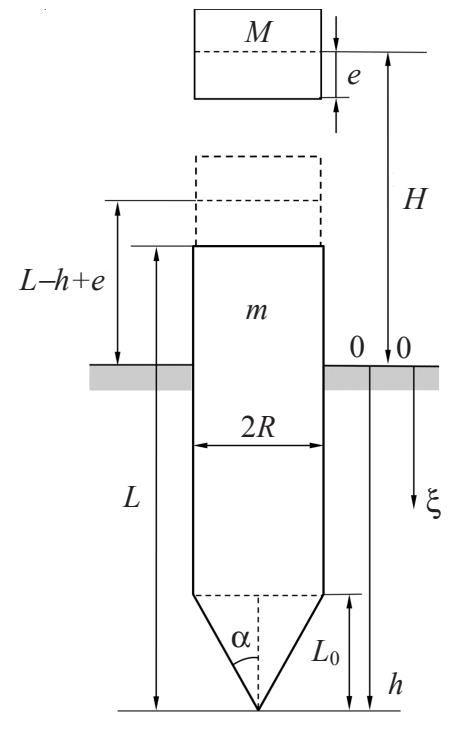

Fig. 1. Notations

After simple algebra we obtain formula for drag force of the pile nose:

$$
D_{\text {nose }}(w)=k_{1} R^{2}\left(Y_{\text {soil }}+\rho_{\text {soil }} \sin ^{2} \alpha w\right), \quad k_{1}=4,
$$


where $D_{\text {nose }}$ is nose contribution to resistance of pile to penetration, $k_{1}$ is parameter that determines shape of nose of pile $\left(k_{1}=4\right), R$ is half side of square in cross section of pile, $\rho_{\text {pile }}$ is average density of pile material, $\alpha$ is angle between side face and axis of the pyramid in nose of pile.

Resistance of the lateral surface of the pile is generally calculated as follows:

$$
D_{\text {lat }}(h)=k_{2} R \int_{0}^{h-L_{0}} p_{\text {lat }}(\xi) \mu_{\text {lat }}(\xi) d \xi, \quad k_{2}=8,
$$

where $D_{\text {lat }}$ is contribution to resistance of pile to penetration from side surface, $h$ is distance from head of pile to ground surface, $k_{2}$ is perimeter of square in cross section of pile $\left(k_{2}=8\right)$, $L_{0}$ is length of nose of pile $\left(L_{0}=R \operatorname{ctg} \alpha\right), p_{\text {lat }}$ is ground pressure on the side surface of the pile, $\xi$ is coordinate measured from ground surface along direction of penetration, $\mu_{\text {lat }}$ is coefficient of friction in interaction of side surface of pile with ground.

The equation of pile motion can be written in the following way:

$$
0.5(M+m) \frac{d w}{d h}=(M+m) g-D_{\text {nose }}(w)-D_{\text {lat }}(h), \quad w=v^{2}
$$

or after substitution $D_{\text {nose }}$ from Eq. (6) and simple transformations in the form:

$$
\frac{d w}{d h}+f w=G(h),
$$

where $v$ is instantaneous velocity of pile and

$$
\begin{gathered}
f=\frac{2 k_{1} R^{2} \rho_{\text {soil }} \sin ^{2} \alpha}{M+m}, \\
G(h)=-\left[-2 g+\frac{2 k_{1} R^{2} Y_{\text {soil }}}{M+m}+\frac{2}{M+m} D_{\text {lat }}(h)\right],
\end{gathered}
$$

Our immediate task is to obtain a relationship between $h^{(i)}$ and $h^{(i+1)}(i=1,2, \ldots)$. This relation can be obtained by writing the solution of Eq. (9) at two points:

$$
w\left(h^{(i+1)}\right)=0, \quad w\left(h^{(i)}\right)=\gamma_{1} h^{(i)}+\gamma_{0} .
$$

Eq. (9) is a linear equation of the first order and its general solution is known; in relation to the problem of modeling pile driving it can be found, for example, in $[10,11]$.

\section{Investigation of the problem}

The solution of Eq. (9) with initial condition $w\left(h^{(i+1)}\right)=0$ can be written as follows:

$$
w(h)=\mathrm{e}^{-F(h)} \int_{h^{(i+1)}}^{h} G(\tilde{h}) \mathrm{e}^{F(\tilde{h})} d \tilde{h}, \quad F(h)=\int_{h^{(i+1)}}^{h} f d x=f\left[h-h^{(i+1)}\right],
$$

or

$$
w(h)=\mathrm{e}^{-f\left[h-h^{(i+1)}\right]} I(h), \quad I(h)=\int_{h^{(i+1)}}^{h} G(\widetilde{h}) \mathrm{e}^{f\left[\widetilde{h}-h^{(i+1)}\right]} d \widetilde{h} .
$$

Then the second relation in Eq. (12) that is written in the form 


$$
\gamma_{1} h^{(i)}+\gamma_{0}=\mathrm{e}^{-f\left[h^{(i)}-h^{(i+1)}\right]} I\left(h^{(i)}\right)
$$

sets the desired relationship between $h^{(i)}$ and $h^{(i+1)}$.

To obtain this dependence in explicit form, we consider below the case when $p_{l a t}$ and $\mu_{\text {lat }}$ do not change in the process of pile penetration, i.e.,

$$
p_{\text {lat }}(\xi)=\text { const, } \quad \mu_{\text {lat }}(\xi)=\text { const. }
$$

Then

$$
D_{\text {lat }}(h)=k_{2} R p_{\text {lat }} \mu_{\text {lat }}\left(h-L_{0}\right)
$$

and $G(h)$ can be represented in the form:

$$
G(h)=\omega_{0}+\omega_{1} h,
$$

where

$$
\omega_{0}=\left[2 g-\frac{2 k_{1} R^{2} Y_{\text {soil }}}{M+m}+\frac{2 k_{2} R p_{\text {lat }} \mu_{\text {lat }} L_{0}}{M+m}\right], \quad \omega_{1}=-\frac{2 k_{2} R p_{\text {lat }} \mu_{\text {lat }}}{M+m}<0 .
$$

Integral $I(h)$ in Eq. (14) can be easily calculated; as a result, we obtain:

$$
\left.I\left(h^{(i)}\right)=\mathrm{e}^{f \cdot\left[h^{(i)}-h^{(i+1)}\right]}\right]\left(\frac{\omega_{0}}{f}+\frac{\omega_{1} h^{(i)}}{f}-\frac{\omega_{1}}{f^{2}}\right)-\left(\frac{\omega_{0}}{f}+\frac{\omega_{1} h^{(i+1)}}{f}-\frac{\omega_{1}}{f^{2}}\right) .
$$

Since

$$
V_{\text {pile }}=k_{3}\left(L-L_{0}\right)+\frac{1}{3} k_{3} L_{0}=k_{3} L-\frac{2}{3} k_{3} L_{0}=k_{3} R^{2} L\left(1-\frac{2}{3} \cdot \frac{L_{0}}{L}\right) \approx k_{3} R^{2} L, \quad k_{3}=4,
$$

where $k_{3}$ is cross sectional area of pile, $V_{\text {pile }}$ is volume of pile,

$$
m=\rho_{\text {pile }} V_{\text {pile }},
$$

and in most cases

$$
\frac{\Delta h^{(i)}}{L}<0.1, \quad \frac{\rho_{\text {soil }}}{\rho_{\text {pile }}}<1, \quad \frac{1}{M / m+1}<0.5, \quad 2 \sin ^{2} \alpha<1,
$$

the following estimation is valid for $f \Delta h^{(i)}\left(\Delta h^{(i)}=h^{(i+1)}-h^{(i)}\right)$ :

$$
\begin{gathered}
f \Delta h^{(i)}=\frac{\Delta h^{(i)}}{L} \cdot \frac{\rho_{\text {soil }}}{\rho_{\text {pile }}} \cdot \frac{m}{M+m} \cdot \frac{2 k_{1} R^{2} L \sin ^{2} \alpha}{V_{\text {pile }}} \approx \\
\approx \frac{\Delta h^{(i)}}{L} \cdot \frac{\rho_{\text {soil }}}{\rho_{\text {pile }}} \cdot \frac{1}{M / m+1} 2 \sin ^{2} \alpha<<1 .
\end{gathered}
$$

Thus

$$
\mathrm{e}^{-f \Delta h^{(i)}} \approx 1-f \Delta h^{(i)} .
$$

Substituting expression for $\mathrm{e}^{-f \Delta h^{(i)}}$ from Eq. (25) to Eq. (20) we obtain after some algebra: 


$$
\begin{aligned}
I\left(h^{(i)}\right) \approx\left(1-f \Delta h^{(i)}\right) & \left(\frac{\omega_{0}}{f}+\frac{\omega_{1} h^{(i)}}{f}-\frac{\omega_{1}}{f^{2}}\right)-\left(\frac{\omega_{0}}{f}+\frac{\omega_{1} h^{(i+1)}}{f}-\frac{\omega_{1}}{f^{2}}\right)= \\
& =-\Delta h^{(i)}\left(\omega_{0}+\omega_{1} h^{(i)}\right) .
\end{aligned}
$$

Eqs. (15), (25) and (26) imply:

$$
\left(1-\Delta h^{(i)}\right)\left(\gamma_{1} h^{(i)}+\gamma_{0}\right)=-\Delta h^{(i)}\left(\omega_{1}+\omega_{2} h^{(i)}\right) .
$$

Eq. (27) allows us to write a desired relationship:

$$
\Delta h^{(i)}=\frac{\gamma_{1} h^{(i)}+\gamma_{0}}{\gamma_{1} h^{(i)}+\gamma_{0}-\left(\omega_{0}+\omega_{1} h^{(i)}\right)} .
$$

The breakout process stops when $\Delta h^{(i)}<\varepsilon_{1}$ or $\left|\Delta h^{(i)}-\Delta h^{(i-1)}\right|<\varepsilon_{2}$ for some $i ; \varepsilon_{1}, \varepsilon_{2}-$ pre-set parameters, criteria for stopping the process of pile driving.

\section{Concluding remarks}

This article presents an approximate approach based on the evaluation of the real values of the parameters that determine the process of driving the pile. Future research under this approach should be developed in the following priority areas:

1) analysis of the accuracy of the proposed model by its presentation with the results of experiments and calculations using other models as well as with recommendations of normative instruments;

2) generalization of the model for the case when the mechanical properties of the soil vary depending on the depth of immersion into the soil.

\section{References}

1. Grutman M.S. Svaynye fundamenty [Pile Foundations]. Kiev. Budivelnik Publ. 1969. 190 p. (In Russian).

2. Svod pravil SP 24.13330.2011. Svaynye fundamenty. Aktualizirovannaya redaktsiya SNiP 2.02.03-85 [SP 24.13330.2011. Pile Foundations. An updated versions of SNiP 2.02.03-85]. 2011. 112 p. (In Russian).

3. Aptukov V.N., Bartolomey A.A., Irundin S.V., Fonarev A.V. Prikladnaya teoriya pronikaniya tela $\mathrm{v}$ grunt pri mnogokratnom udare. Zadacha o rasshirenii sfericheskoy polosti $\mathrm{v}$ grunte [Applied theory of penetration of a body into soil under multiple impact. The problem about spherical cavity expansion in ground]. V sb.: Osnovaniya i fundamenty $v$ geologicheskikh usloviyakh Urala. Sb. nauchnykh trudov. Perm, Permskiy gosudarstvennyy tekhnicheskiy universitet [In Proc.: Foundations and Foundations in the Geological Conditions of the Urals. Collection of scientific papers. Perm. Permian State techical university]. 1999. P. 9-19 (in Russian).

4. Yu H.S. Cavity Expansion Methods in Geomechanics. Dordrecht. Kluwer. 2000. 385 p.

5. Bulatov G. Ya., Kolosova N.B. Effektivnost svay razlichnykh form poperechnogo secheniya [Efficiency of piles of various cross-sectional shapes]. Inzhenerno-stroitelnyy zhurnal [Magazine of Civil Engineering]. 2013. No 7(42). P. 67-76 (In Russian).

6. Shadunts K.Sh. O vzaimodeystvii bokovoy poverkhnosti svay s okruzhayushchim ikh gruntom osnovaniya [On the interaction of the lateral surface of piles with the surrounding soil of the base]. Nauchnyy elektronnyy zhurnal Kubanskogo gosudarstvennogo agrarnogo universiteta [Scientific Electronic Journal of the Kuban State Agrarian University]. 2006. No 19(3) (in Russian).

7. Rakhmatulin Kh.A., Sagomonyan A.Ya., Alekseev N.A. Voprosy dinamiki gruntov [Soils Dynamics]. Moscow. MGU Publ. 1964. 240 p. (in Russian).

8. Ledenev V.V., Monastyrev P.V., Kulikov G.M., Plotnikova S.V. Raschetnye modeli dlya 
proektirovaniya konstruktsiy $i$ zdaniy [The Calculation Models for Design of Structures and Buildings]. Tambov. TGTU Publ. 2016. 296 p. (In Russian).

9. Dalmatov B.I. Mekhanika gruntov, osnovaniya i fundamenty [Soil Mechanics, Bases and Foundations]. Moscow. Stroyizdat Publ. 1981. 319 p. (In Russian).

10. Aptukov V.N., Fonarev A.V. Priblizhennaya otsenka glubiny pronikaniya svai v grunt pri mnogokratnom udare [Approximate estimation of penetration depth of a pile into soil under multiple impacts]. Vestnik Permskogo universiteta. Matematika. Mekhanika. Informatika [Perm State National Research University Bulletin. Ser. Mathematics. Mechanics. Informatics]. 2010. No 2(2). P. 41-45 (In Russian).

11. Malanin V.V., Pensky O.G. Sopryazhennye modeli dinamiki impulsno-teplovykh mashin i pronikaniya nedeformiruemykh tel v sploshnuyu sredu [Conjugate Models of Dynamics of Heat Impulse Machines and Penetration of Rigid Bodies into Continuous Medium]. Perm. Permian State University Press. 2007. 198 p. (In Russian).

12. Tarasov V.N. Teorija zabivki svai $v$ grunt padaiushchim gruzom [Theory of pile driving into the ground by a falling load]. Glava 7. In: Teoriya udara $v$ stroitelstve $i$ mashinostroenii. [Chapter 7. The Theory of Impact in the Construction and Engineering Industry]. Moscow. Assotsiatsiya stroitelnykh vuzov. 2006. 336 p. (In Russian).

13. Take W.A., Valsangkar A.J., Randolph M.F. Analytical solution for pile hammer impact. Computers and Geotechnics. 1999. Vol. 25(2). P. 57-74.

14. Ben-Dor G., Dubinsky A., Elperin T. Engineering Models in High-Speed Penetration Mechanics and Their Applications (A Two-Volume Set. Vol. 1. Engineering Models; Vol. 2: Applied Problems). World Scientific. 2019. 1076 p.

15. Vitman F.F., Stepanov V.A. Vliyanie skorosti deformirovaniya na soprotivlenie deformirovaniyu materialov pri skorostyakh udara $10^{2}-10^{3} \mathrm{~m} / \mathrm{s}$ [Effect of strain rate on resistance of metals to deformation at impact velocities of 100-1000 m/s]. V kn.: Nekotorye problemy prochnosti tverdogo tela [In book: Some Solid Strength Problems]. Moscow. Leningrad. AN SSSR Publ. 1959. P. 207-221 (In Russian).

\section{Список литературы}

1. Грутман М.С. Свайные фундаментыл. Киев: Будівельник, 1969. 190 с.

2. Свод правил СП 24.13330.2011. Свайнье фундаменты. Актуализированная редакция СНиП 2.02.03-85. 2011. $112 \mathrm{c.}$

3. Аптуков В.Н., Бартоломей А.А., Ирундин С.В., Фонарев А.В. Прикладная теория проникания тела в грунт при многократном ударе. Задача о расширении сферической полости в грунте. В сб.: Основания и фундаменты в геологических условиях Урала. Сб. научных трудов. Пермь: Пермский гос. техн. ин-т, 1999. С. 9-19.

4. Yu H.S. Cavity Expansion Methods in Geomechanics. Dordrecht. Kluwer. 2000. 385 p.

5. Булатов Г.Я., Колосова Н.Б. Эффективность свай различных форм поперечного сечения. Инженерно-строительный журнал. 2013. №7(42). С. 67-76.

6. Шадунц К.Ш. О взаимодействии боковой поверхности свай с окружающим их грунтом основания. Научный электронный журнал Кубанского государственного аграрного унma. 2006. №19(3).

7. Рахматулин Х.А., Сагомонян А.Я., Алексеев Н.А. Вопросы динамики грунтов. М.: Изд-во МГУ, 1964. 240 с.

8. Леденёв В. В., Монастырёв П. В., Куликов Г. М., Плотникова С.В. Расчетные модели для проектирования конструкций и зданий. Тамбов: Изд-во ТГТУ, 2016. 296 с.

9. Далматов Б.И. Механика грунтов, основания и фундаментыл. М.: Стройиздат, 1981. 319 c.

10. Аптуков В.Н., Фонарев В.Н. Приближенная оценка глубины проникания сваи в грунт при многократном ударе. Вестник Пермского университета. Сер.: Математика. Механика. Информатика. 2010. Вып. 2(2). С. 41-45.

11. Маланин В.В., Пенский О.Г. Сопряженные модели динамики импульсно-тепловых машин и проникания недеформируемых тел в сплошную среду. Пермь: Изд-во Пермского унта, 2007. 198 с. 
12. Тарасов В.Н. Теория забивки свай в грунт падающим грузом. Гл. 7. В кн.: Теория удара в строительстве и машиностроении. М.: Изд-во Ассоциации строительных вузов, 2006. $336 \mathrm{c}$

13. Take W.A., Valsangkar A.J., Randolph M.F. Analytical solution for pile hammer impact. Computers and Geotechnics. 1999. Vol. 25(2). P. 57-74.

14. Ben-Dor G., Dubinsky A., Elperin T. Engineering Models in High-Speed Penetration Mechanics and Their Applications. (A Two-Volume Set. Vol. 1. Engineering Models; Vol. 2. Applied Problems). World Scientific. 2019. 1076 p.

15. Витман Ф.Ф., Степанов В.А. Влияние скорости деформирования на сопротивление деформированию материалов при скоростях удара $10^{2}-10^{3} \mathrm{~m} / \mathrm{c}$. В кн.: Некоторые проблемы прочности твердого тела. М.-Л.: Изд-во АН СССР. 1959. С. 207-221.

\title{
МОДЕЛЬ ЗАБИВАНИЯ СВАЙ МНОГОКРАТНЫМИ УДАРАМИ ПАДАЮЩЕГО МОЛОТА
}

\section{Дубинский А.В.}

\author{
Университет им. Бен-Гуриона в Негеве, Беэр-Шева, Израиль
}

Расчеты, связанные с забивкой свай, играют важную роль в строительстве. Поэтому соответствующие процессы контролируются нормативными документами, в том числе необходимыми формулами, которые сопровождаются многочисленными таблицами и графиками, позволяющими использовать методики в конкретных условиях строительства. Основой таких прикладных методов являются результаты исследований в области механики. Результаты этих исследований широко представлены в литературе. Данная статья выполнена в рамках таких исследований.

В статье представлен приближенный подход, основанный на оценке реальных значений параметров, определяющих процесс забивки сваи. Предложенный подход позволил получить приближенную формулу для расчета движения сваи в грунте вследствие последовательных ударов свободно падающего молота. Намечены пути совершенствования моделей в рамках этого подхода. Исследования рекомендуется развивать в следующих приоритетных областях: анализ точности предлагаемой модели путем ее сопоставления с результатами экспериментов и расчетов с использованием других моделей, а также с рекомендациями нормативных документов; обобщение модели на случай, когда механические свойства почвы изменяются в зависимости от глубины погружения в грунт.

Ключевые слова: грунт, свая, проникание, молот, забитие, моделирование, расчет. 